\title{
グラウト充てん式鉄筋継手に関する研究の動向
}

\author{
林 芳尚*1 ・ 中塚 佶*2 ・鈴木計夫*3
}

\begin{abstract}
概 要 鉄筋コンクリート部材のプレキャスト工法において, グラウト充てん式鉄筋継手は, 後打ちコンクリートが不 要で，また，太径鉄筋への良好な適用性ならびに鉄筋位置の誤差や傾斜への対応が可能であるという特徴を持つ。それ 故, 柱や壁のような鉛直部材の接合に多く採用されるようになり, 今後も利用の増大, 継手の高性能化が進むと考えられ る。同継手は, その優れた施工性から, 近年, 新しい夕イプのものも開発され, 現在までに多くの研究がなされているも のの，それらをまとめた報告は見られない。本報では，グラウト充てん式鉄筋継手についての理解と今後の開発等の参考 に資するため, 同継手の単体としての性能および応力伝達機構, 部材における性能およびその施工性に関する研究の現状 を紹介した。

キーワード : 鉄筋継手, スリーブ, グラウト, 性能, プレキャスト
\end{abstract}

1.はじめに

我が国は,これから 21 世紀初頭に向けて，人類がこ れまでに経験したことのないスピードで高龄化社会を迎 えようとしている。また, 戦後構築してきた多くの社会 資本の更新期が同時に訪れようとしている。このような 状況を背景に，鉄筋コンクリート構造物の施工において は, 現場の省人化, 作業の単純化, 作業環境の改善, 地球環境への配虑等から部材のプレキャスト（以下， $\mathrm{PCa}$ と略記する）化がますます増加すると考えられ る $^{1) \sim 3)}$ 。

鉄筋コンクリート部材の PCa 工法では, 構造および 施工上，鉄筋の継手がキーポイントになるので，従来の 重ね継手, 圧接継手などに加えて機械式継手, 溶接式継 手等が種々開発されてきている ${ }^{4)}$ 。中でもグラウト充て ん式鉄筋継手は, 後打ちコンクリートが不要で, また, 太径鉄笳への良好な適用性ならびに鉄筋位置の誤差や傾 斜への対応が可能であるという特徴を持つため, 近年で は多くのPCa 工法において, 特に柱や壁のような鉛直 部材の接合に多用されてきている。

我が国では 1970 年代前半から, グラウト充てん式鉄 筋継手のプロトタイプとも考えられる鋼管や異形パイプ をスリーブとして用いた継手に関する研究 ${ }^{5), 6)}$ がみられ るが, グラウト充てん式鉄筋継手としてはアメリカの Alfred A Yee \& Associates Inc. と日曹マスタービル ダーズ㑣が技術提携により開発し，日本で始めて実用化 された NMB スプライススリーブ7) 9) が本格的な最初 の継手である。当初, NMB スプライススリーブしか実 用化されていなかったため, 研究のほとんどは同継手に ついてのものであった。しかし，1990 年代に入ると

\footnotetext{
*1 はやし・よしひさ/侏奥村組 本社建築部（正会員）

*2 なかつか・ただし/大阪大学講師 工学部建築工学科 (正会員)

*3すずき・かずお／大阪大学教授同上（正会員）
}

PCa 工法が数多く実施されるようになり，また，コス 卜低減や適用範囲の拡充等の要求から, ネジスリーブ, トップスジョイント，チェッカースリーブ等といった新 しい製品が開発され，それら各製品の性能評価資料関連 の実験結果等も多数発表されるようになってきた。

鉄筋継手全般に関しては，社日本コンクリート工学協 会主催の「鉄筋の継手および定着の設計・施工に関する シンポジゥム」論文集 ${ }^{10)}$ や文献 4) 等に詳しい。しか し, 優れた施工性から今後その適用が一層増加すると考 えられるグラウト充てん式鉄筋継手に関しては，現在ま でに多くの研究がなされているものの，それらをまとめ たような系統的な解説は見られない。本報では，グラウ 卜充てん式鉄筋継手についての理解と今後の開発等の参 考に資するため，同継手の単体としての性能，部材にお ける性能およびその施工性等に関する研究の現状を紹介 する。

\section{2. 継手性能}

建築構造物では, グラウト充てん式鉄筋継手のような 特殊な継手は建設省住宅局建築指導課長の認定を受けた ものでなければ害用化できず, 1972 年から性能評価が 実施されている。継手性能の評価基準は新しい継手が開 発されるに伴い検討事項が追加され ${ }^{11)}$, (財)日本建築セ ンターの RPCJ 委員会による継手性能判定基準第一次 案 (1974) および二次案 (1975), 土木学会指針 (1979), JIS 案 (1980) 等の提案がなされたが，それらは「継手 性能判定基準 (1982) 」12) として総合的にとりまとめられ ている。また，実績の蓄積ならびに認定業務の簡素化等 の理由で, 現在, 継手の性能評価は, 建築指導課長によ る認定を取りやめ, 財)日本建築センター等の公的な機関 による審査によって行われている13)。

\section{1 単体としての継手性能}

グラウト充てん式鉄笳継手単体は, 図-1に示される 


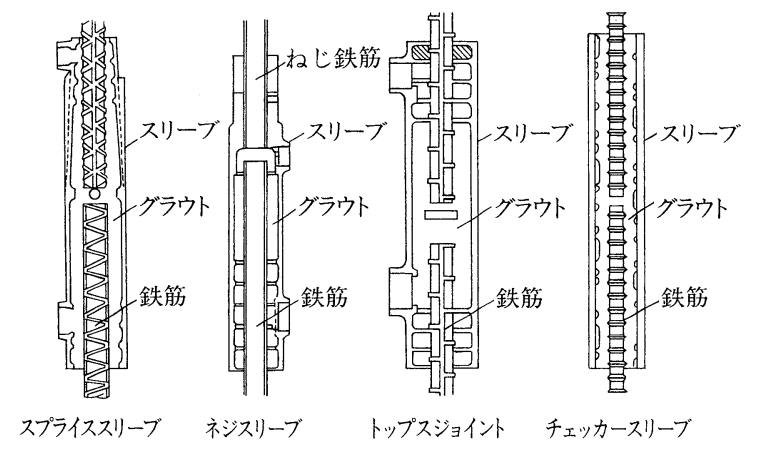

図-1＼cjkstart各種のグラウト充てん式鉄筋継手

（a）定着長の影響 $\quad$ (b) グラウト強度の影響

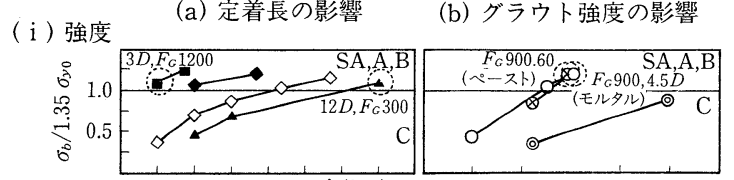

(ii) 剛性

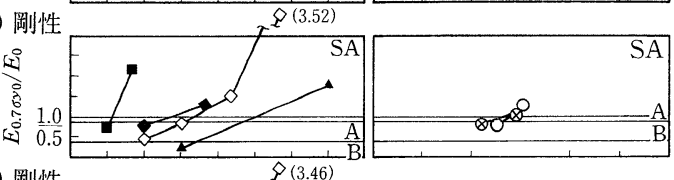

(iii) 剛性

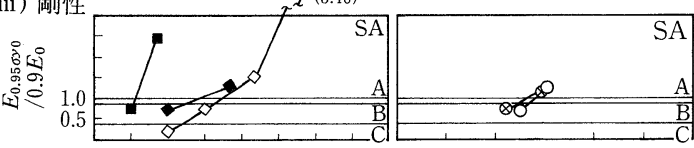

（iv）靶性

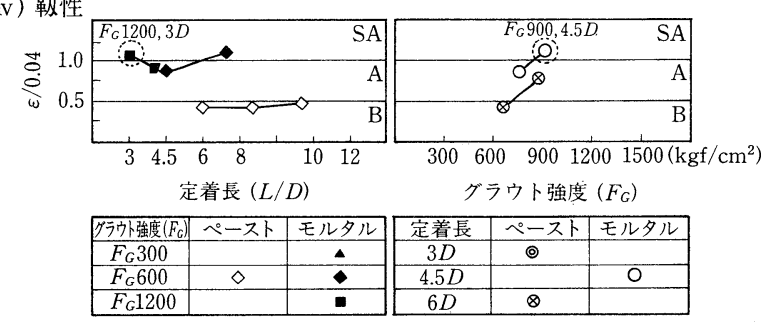

注：強度による影響を明確にするため, $F_{G} 300 \mathrm{~A}, \mathrm{~B}$ はまとめて $F_{G} 300$ とする ( $F_{G} 600,900$ も同様).

ここで $\sigma_{y_{0}}$ : 母材の規格降伏点 (または耐力)

$\sigma_{b}:$ 接合鉄筋の引張り強度

$E_{0}:$ 母材の規格降伏点の $70 \%$ の応力における母材の割線剛性

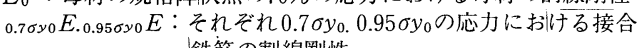

$\varepsilon \quad:$ 接合鉄筋の終局ひずみ

図一2 継手性能に及ぼす各種要因の影響

ように，スリーブ内で向きをあわせるように配置された 接合鉄筋とスリーブの間を，グラウト材で充てんして一 体化し，スリーブを介して鉄筋の力を一方から他方へと 伝達するものである。したがって，その強度などの継手 性能ならびにそれらの巨視的な性能に関連する，鉄筋之 コンクリートとの微視的な応力伝達特性, 例えば付着応

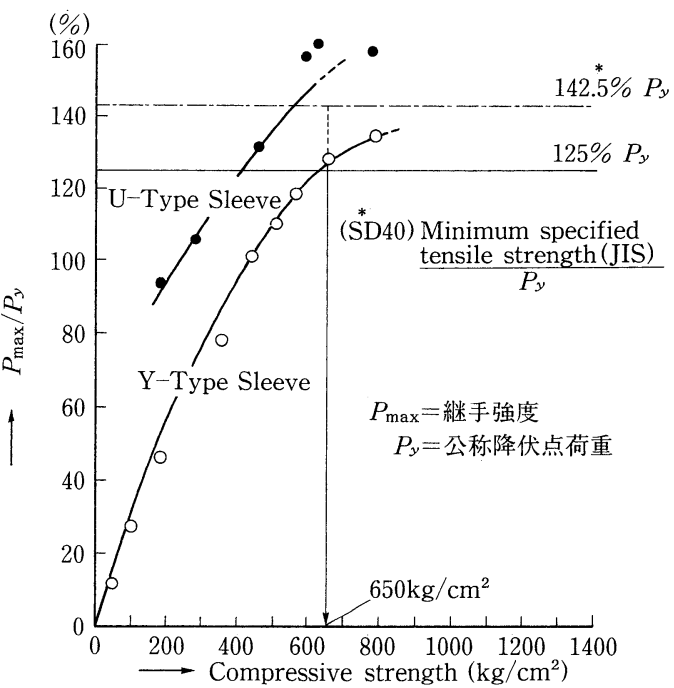

図-3グラウト圧縮強度と継手強度

力度一すべり（以下 $\tau-s$ と略記する）特性などは, グ ラウトの種類と強度, 鉄筋の接合長さや節形状, 接合鉄 筋の傾斜等の影響を受けると考えられる。以下に，同継 手の単体としての性能に及ぼす各種要因の影響について 述べる。

（1）各種要因の影響

継手性能は主に継手性能判定基準による試験（一方向 引張り試験および弾塑性正負繰返し試験等）に従って調 ベられている。

図-2 ${ }^{14)}$ は, 継手性能判定の規定項目である継手の強 度，剛性および靱性に及ぼすグラウトの種類と強度およ び定着長の影響を示したものである。同図では, 継手性 能判定基準による $\mathrm{SA}$ 級 ${ }^{12)}$ の性能下限值を 1 として各 試験結果を示している。また, 図- $3^{15)}$ は, 2 種類のス リーブを用いてグラウト強度の継手強度への影響を調べ たものである。図一 2 および図ー 3 によれば, 継手強度 は, グラウト強度の増大によってほぼ比例的に増大し, 定着長を長くすることによっても向上する。

継手の剛性および鞄性については発表された文献は少 ないが，図-2 によれば，継手の剛性は継手強度と同様 に, 定着長あるいはグラウト強度が大きくなるに従って 増大する。剛性に及ぼす定着長の影響は継手強度に対す るそれよりも顕著である。継手の勒性は，モルタルグラ

State of the Arts on Study of Grout-Filled Coupling Sleeves

By Y. Hayashi, T. Nakatsuka and K. Suzuki

Concrete Journal, Vol. 34, No. 4, pp. 15 23, April 1996

Synopsis Recently, the grout-filled coupling sleeve has a tendency to be used frequently because of its superior construction efficiency, such as unnecessity of postcast concrete, large allowable limit to arrangement of reinforcing bars. This report mainly introduces on mechanical preformance, stress transmission mechanism of the groutfilled coupling sleeve, mechanical characteristics of precast concrete members with the sleeves and important aspects on assemblage of precast concrete members.

Keywords : grout-filled coupling sleeve, mechanical performance, precast concrete 
ウトおよび高強度グラウトの使用によって向上する傾向 を示すが，定着長の影響は明確ではない。また，いずれ の性能においても他の条件が同じであれば，モルタルグ ラウトの方がペーストグラウトより優れた性能を与えて いる。これらのことは, 実際の継手で採用されるモル夕 ルグラウト材の高強度化が継手性能の一層の高度化に有 効であることを示唆している。

継手の施工性に大きく関係する継手内鉄筋の偏心, 傾 斜あるいはグラウト注入後における鉄筋のわずかな移動 の影響についても調べられている。図-4 $4^{16)}$ にその結果 を示すが, 上記のような施工誤差が生じた場合でも, 継 手強度および繰返し後の変形量ともに標準的な施工で製 作された継手のそれと同等である。このことは, 本継手 形式が, 他の継手形式であるネジ式や溶接式に比べて鉄 筋の位置誤差吸収が大きく, 施工性に優れていることを 示している。

図-58) は，同継手の耐火性についての研究結果であ る。継手単体の表面温度 3 種 $(200,300,500$ 度）之継 手内部の鉄筋表面温度との差 3 種 $(0,80,120$ 度) を組 み合わせた各種試験体の単調引張り試験における継手強 度および継手の伸び率を示したものである。同図による と, 継手の平均表面温度が約 400 度以下の場合, 継手の 強度は, 加熱を受けないものに比へてて低下しない。しか し, 約 450〜500 度に達したものは約 20\% 程度低下して いる。また，スリーブ表面温度と内部鉄筋表面との温度 差による影響は特に見られなかった。ただし，加熱を受 けた試験体は, 加熱を受けなかった試験体に比べて, 継 手の伸び率が大きかった。さらに，3 種 $(20,30,40$ $\mathrm{mm}$ ) のかぶり厚さを持つ継手を埋め込んだ部材に, JIS A 1304 による 3 時間加熱を与えた場合の影響も調 べられている ${ }^{8}$ が, 加熱の有無による影響は継手強度お よび伸び率ともに大差はなかった。

継手の疲労特性についての研究結果を図-6 ${ }^{15)}$ に示 す。同図は, 2 種のスリーブを用いて 150 回繰り返し引 張り荷重に対する継手性能を比較したもので, 繰り返し 時の除荷点を鉄筋の公称降伏点荷重 $\left(P_{y}\right), 2 / 3 P_{y}$ およ び1/2 $P_{y}$ とし, 再載荷点を $0.5 \mathrm{t}$ とした場合の繰り返 し後の強度を示している。同図によると, 単調引張り試 験では両者の差はほとんどないが，テーパーを持つス リーブはストレート型スリーブに比べて繰り返し後の強 度が優れている。

\section{（2）応力伝達機構}

継手の応力伝橽機構は，スリーブや接合鉄筋のひずみ 分布, ならびにそれらデー夕に基づいて算出された $\tau-s$ 特性, および同継手内部に発生するひび割れや変形状況 の観察等から調へらられている。

継手全域のスリーブおよび継手内鉄筋のひずみ分布を 示している図 $-7^{17)}$ によれば, 継手中央に近づくに従っ てスリーブのひずみは増大し継手中央で最大のひずみを
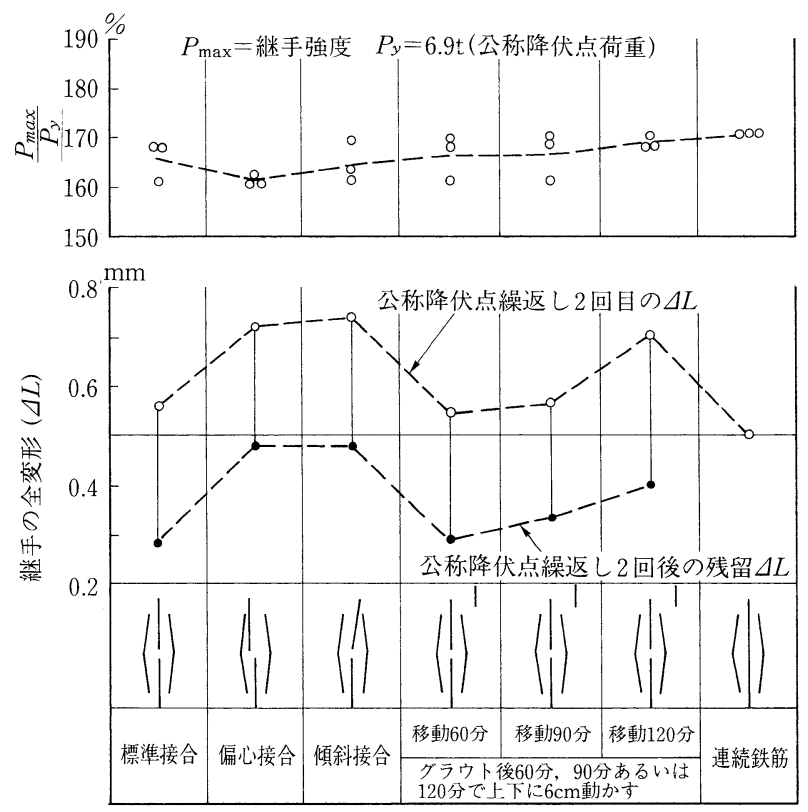

図-4 鉄筋の偏心および移動の影響

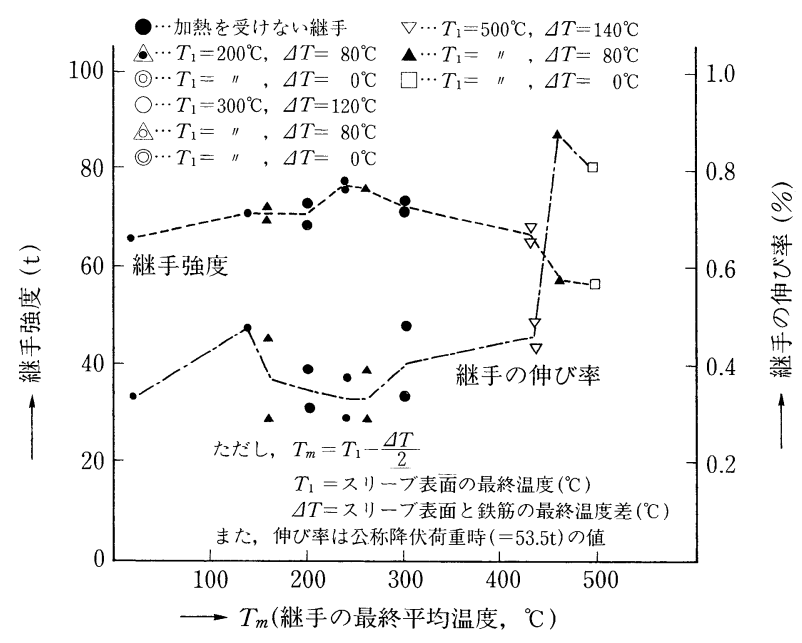

図-5＼cjkstart継手強度および伸び率に及ぼす加熱の影響

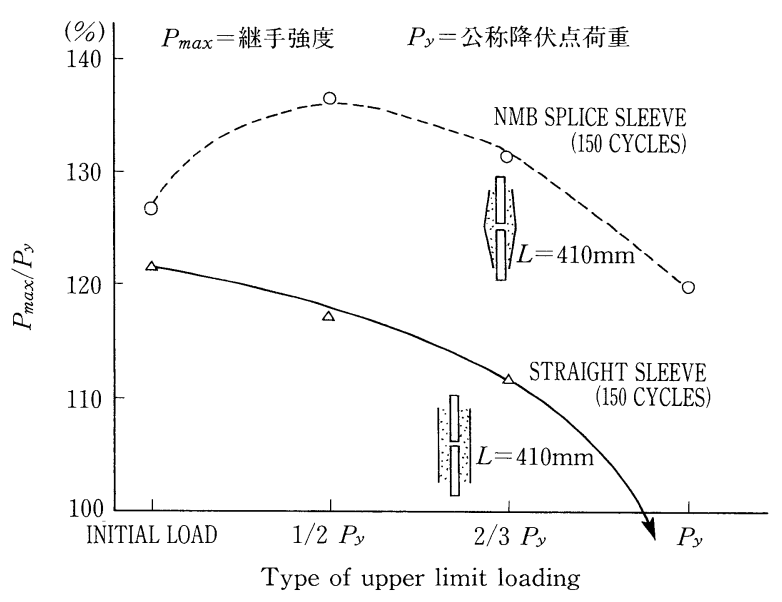

図-6 継手の疲労特性

示す。鉄筋のひずみはそれに対応して，スリーブ内に入 るに従って小さく端部でゼロになる。また，スリーブ端 の約 $1 D$ ( $D$ : 鉄筋径) 部分の鉄筋ひずみはほぼ一定 で, この間の応力伝達が見られない。他のスリーブを持 つ継手の研究 ${ }^{18)}$ でも同様の結果が示されており,この 
現象は，スリーブの端部分に生じたグラウトのコーン破 壊に起因するものと考えられる。

継手性能に直接関係する基本デー夕である $\tau-s$ 特性 が，鉄筋が拔け出し破壊する場合，ならびに鉄筋降伏後 に拢け出し破壊する場合について調べられている。 図- ${ }^{14)}$ は降伏せずに抜け出して破壊した試験体で，取 り上げた要因のみが異なる試験体の比較から, 諸要因が $\tau-s$ 関係に及ぼす影響を示したものである。同図による と鉄筋の未降伏部分での $\tau-s$ 関係は, 鉄筋の定着長, 降伏強度, 径およびスリーブ内での偏心にかかわらず, グラウトが同じであればほぼ同様であり，2.1 項で記述 した継手性能についての研究結果と対応している。一 方, 鉄筋の降伏が生じた以降に付着破壊した試験体で は, 鉄筋が降伏する位置での $\tau-s$ 関係が，図-9 ${ }^{14)}$ に示 すように鉄筋が未降伏の場合と大きく異なり, 当該位置 が降伏するときのパルス的なピークと, その後比較的小 さいほぼ一定の付着応力度を持つものであることを示し ている。

付着応力度とグラウト強度の関係も調べられている。 図-10 ${ }^{14)}$ は，鉄筋未降伏部分での $\tau-s$ 関係における $\tau$ の最大值 $\left(\tau_{b m}\right)$, および鉄筋既降伏部分での $\tau$ の最大值 $\left(\tau_{b y}\right)$ とグラウト強度の関係を示したものである。同図 によると，両者はいずれのグラウト材を使用した場合も グラウト強度に比例して増加すること, また，同じグラ ウト強度に対してモルタルグラウトではペーストグラウ トに比へて約 $25 \%$ 大きい $\tau_{b m}$ の得られることが指摘さ れている。

図-11 ${ }^{14)}$ は，鉄筋未降伏および既降伏部分に対して それぞれ $\tau_{b m}$ および $\tau_{b y}$ の付着応力度を仮定する継手 強度算定式によって, 本継手の強度と破壊モードが推定 可能であることを示している。

継手内部に発生するひび割れおよび変形状況が，コン クリート中に埋めこまれた異形鉄筋の引張り載荷後のク ラック発生状況等を視覚化した樹脂注入法と同様の方
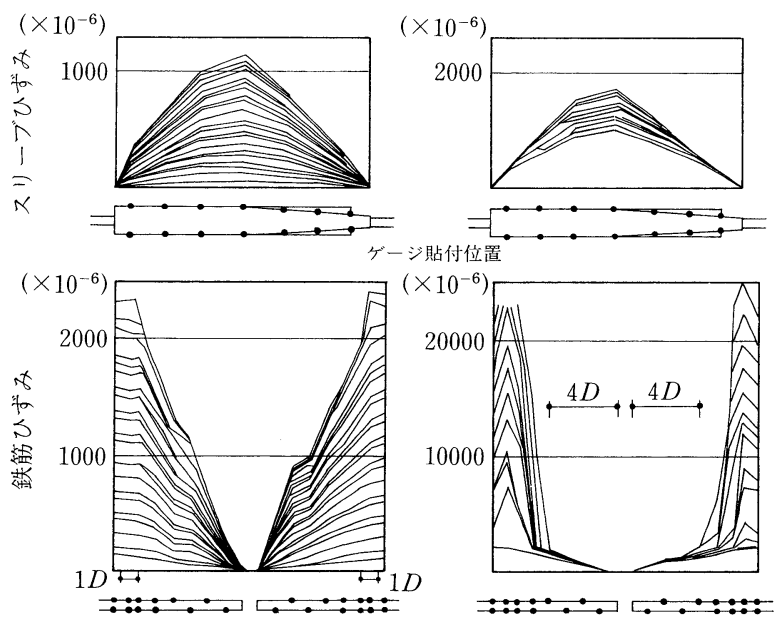

鉄筋降伏以前

鉄筋降伏以降

図-7 スリーブおよび接合鉄筋のひずみ分布

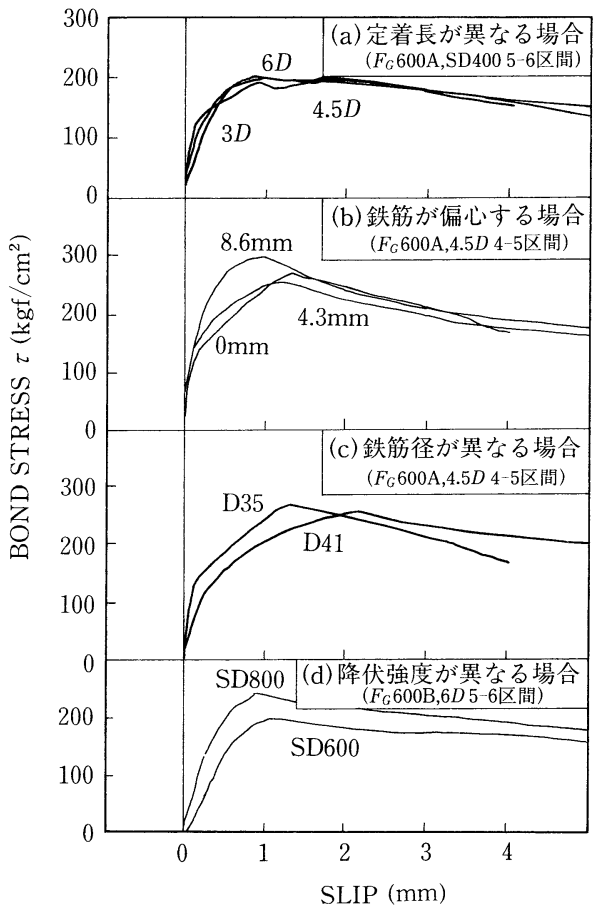

図-8 $\tau-s$ 関係に及ぼす諸要因の影響

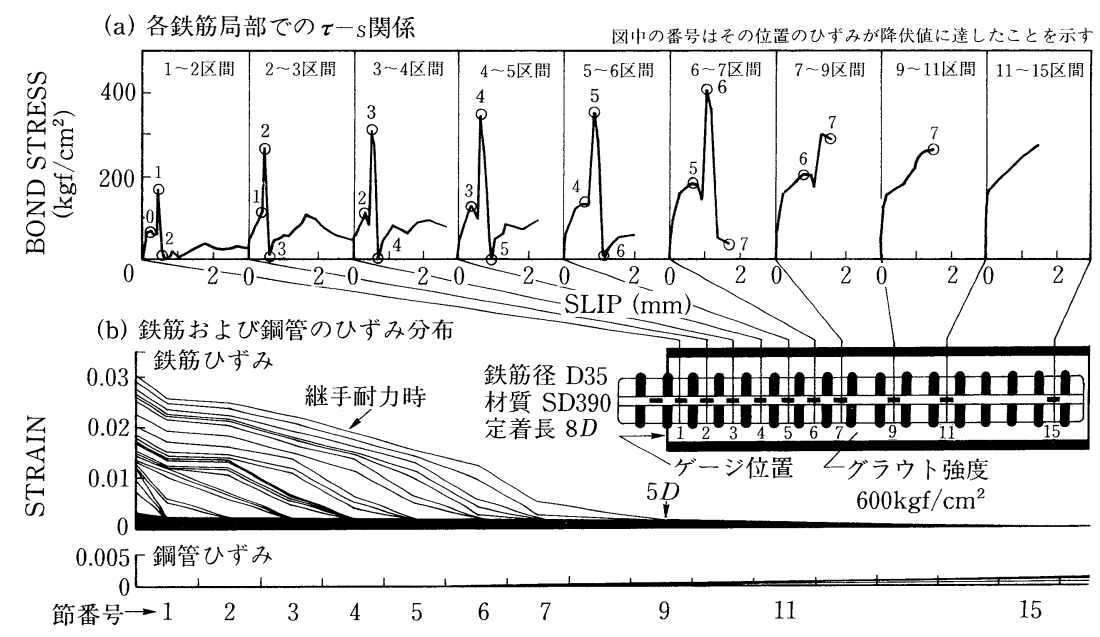

図-9 鉄筋が降伏した試験体の $\tau-s$ 関係およびひずみ分布 


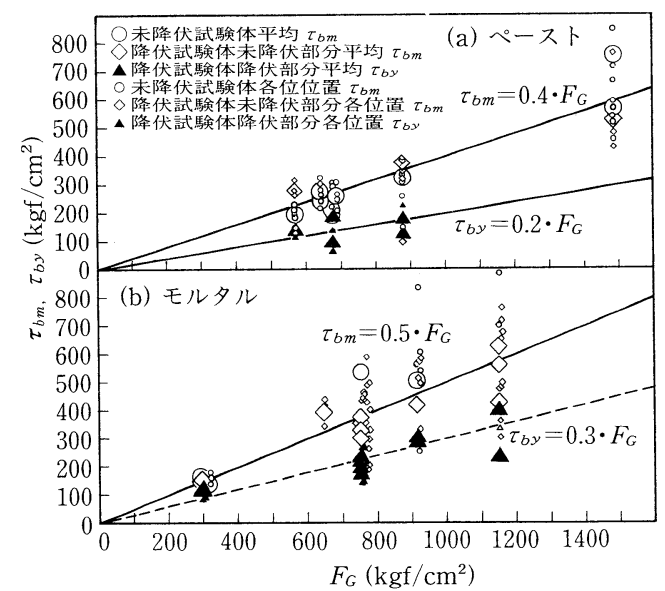

図-10 グラウト圧縮強度と最大付着応力度との関係

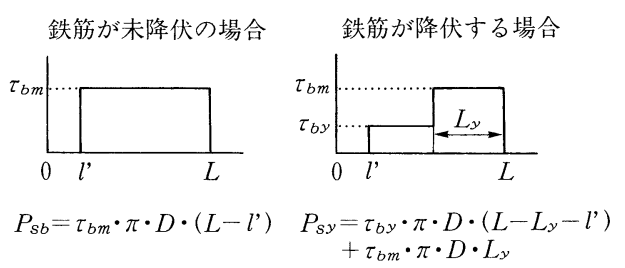

$P_{s b}:$ 継手強度 (鉄筋が降伏せずに抜け出し破壞) $P_{S y}$ : 継手強度 (鉄筋が降伏後抜け出し破壞) $L:$ : 定着長 $\quad L_{y}: P_{y} /\left(\tau_{b m} \cdot \pi \cdot D\right)$ $l '$ : 鉄筋の一節長さ $\quad P_{y}$ : 鉄筋の降伏強度

（a）材軸方向の $\tau$ 分布仮定と継手強度算定式

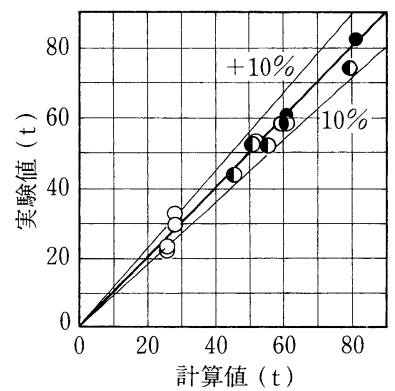

(b) 継手強度推定結果

図-11 継手強度推定式と推定結果

法 ${ }^{19)}$ で観察されている。写真-1 ${ }^{20)}$ は, 前述した異なる 2 種の破壊タイプでの継手内部に発生するひび割れ変形 状況についてのものである。写真によると, 継手内部の ひび割れおよび変形状況には, 載荷端側のコーン状ひび 割れ，鉄筋の節頂部を結ぶひび割れ，鉄筋降伏部分の細 り，鉄筋節部のずれ变位および鉄筋非載荷端側の抜け出 し等が観察される。図-12 ${ }^{20)}$ はひび割れおよび変形状 沉を数值化したものである。同図によると，特に鉄筋降 伏領域では，載荷端側に向かう方向で顕著に増大するず れ変位および細りが見られる。これに対し，鉄筋未降伏 領域では細りは殆どみられず，それぞれの節位置でほぼ 同様のずれ変位が生じ，このことから付着破壊はスリー ブ内鉄筋の全域が一様にずれ変位するものであると指摘

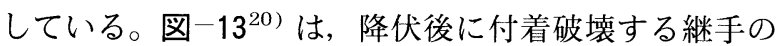
各節位置におけるずれ変位量を載荷段階別に示したもの

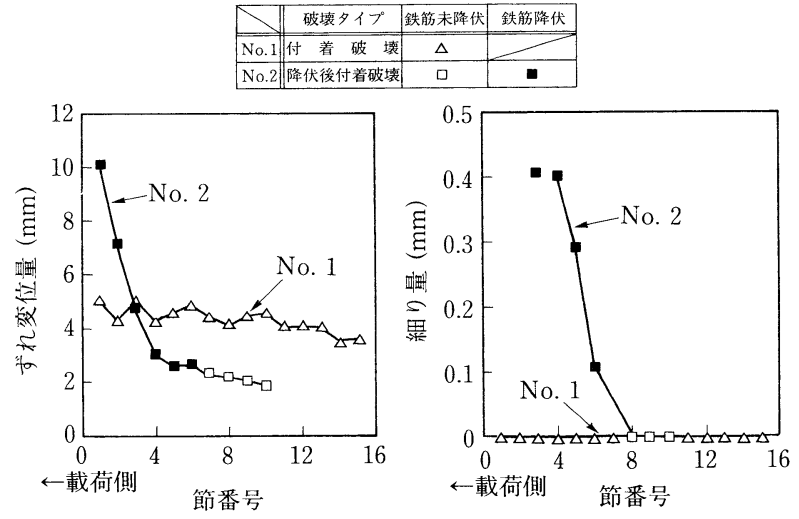

(a) 鉄筋の節位置と変位量の関係

（b）鉄筋の節位置と細り量の関係 図-12 継手内における鉄筋のずれ变位および細り

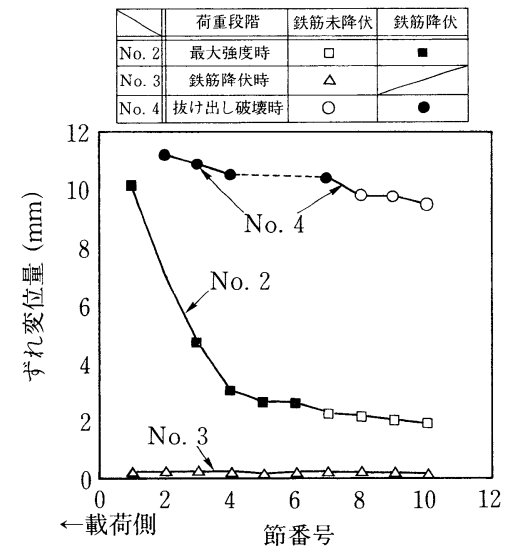

図-13 鉄筋ずれ変位の荷重段階による変化

であるが，次のような観察結果が述べられている。鉄筋 母材部の鉄筋降伏直後の荷重段階では, 鋼管端から継手 内鉄筋に向かう斜めひび割れ，およびめり込みによると 思われる節のずれ変位が観察され，最大強度時では，鋼 管端部に向かって急増する降伏領域におけるずれ变位, ならびに未降伏領域におけるほぼ同様のずれ変位が見ら れる。鉄筋抜け出し後では, 降伏および未降伏領域にお いてほぼ一様なずれ変位の生じていることが分かる。

\section{$2.2 \mathrm{PCa}$ 部材としての性能}

グラウト充てん式鉄筋継手を用いた柱，はりおよび壁 の $\mathrm{PCa}$ 部材が，同じ条件で一体製作した試験体と同等 以上の性能を示すかどうかが比較検討されている。

図-14 ${ }^{21)}$ は，同じスリーブを用いた 66 体の柱の試験 体について, 曲げ強度の実験值と計算值 ${ }^{22}$ を比較した 結果である。実験值は平均的に計算值の 1.17 倍で与え られ，この関係は，一体打設した試験体の場合と殆ど同 じであった。さらに，部材の変形性能に関する検討とし て, 限界変形時の部材角（荷重が最大荷重の 8 割以下に 低下した時の変形角）とせん断余裕度（せん断強度の計 算値/曲げ強度の計算値）の関係, 塑性率（降伏時の変 形に対する限界変形）とせん断余裕度の関係, 各種構造 因子と限界変形時の部材角の関係について同様の比較が 行われているが21), どの項目においても $\mathrm{PCa}$ 部材と一 


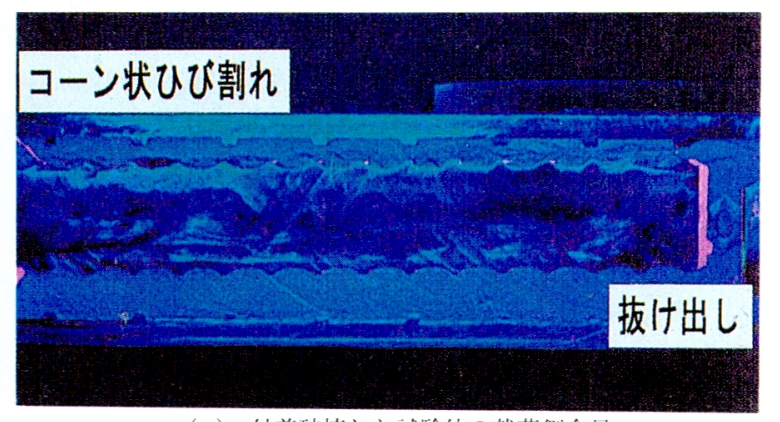

（a）付着破壊した試験体の載荷側全景

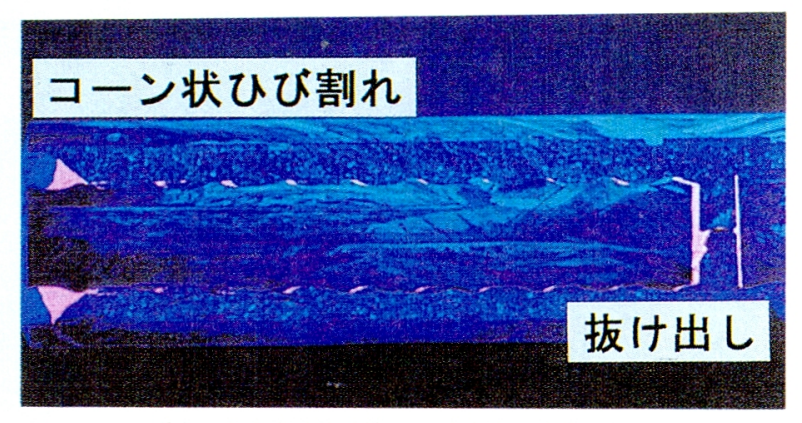

（b）降伏後付着破壊した試験体の載荷側全景

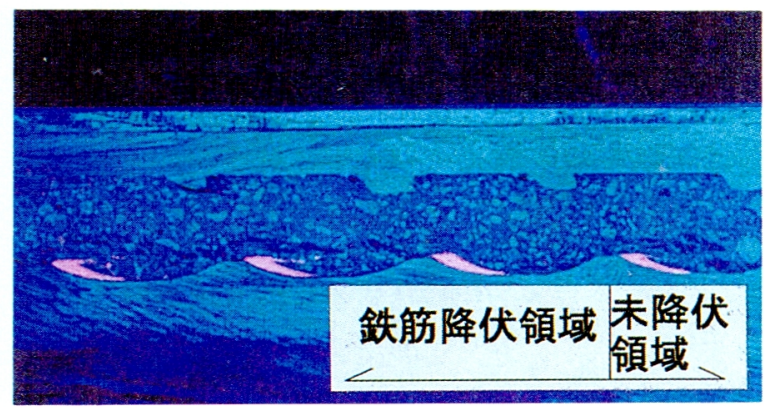

（c）節頂部を結ぶひび割れおよび鉄筋節部の隙間状況

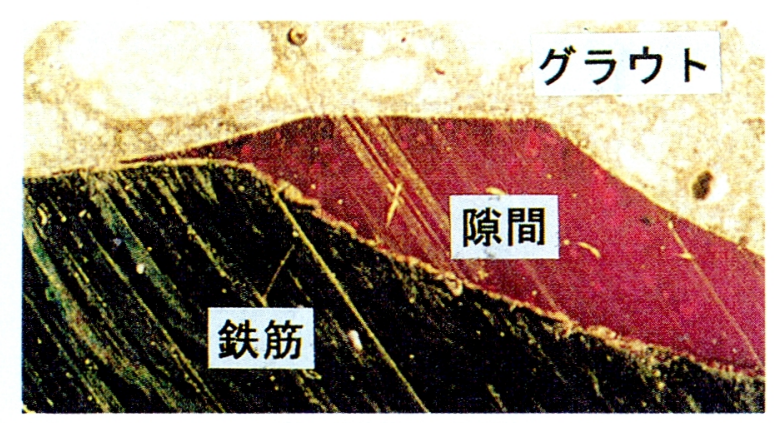

（d）鉄筋節部の隙間状況

写真-1 継手内の变形およびひび割れ状況

体打設した部材との間に明確な違いは見られないと報告 されている。

図一14の場合と異なる継手を用いた柱試験体における 荷重一部材角関係の例を図-1523) に示す。柱への軸力 の有無および柱のフープ筋のピッチ等に関わらず, $\mathrm{PCa}$ 部材の強度および変形性能は, 一体打設した部材のそれ らとほぼ同等なものになっている。

図一16 ${ }^{24)}$ は, スリーブ外周面の状態を溶接ビードあ るいはワックス塗布によって付着をなくした場合, 力学 性能が一体打設した試験体とどのように異なるかを調べ
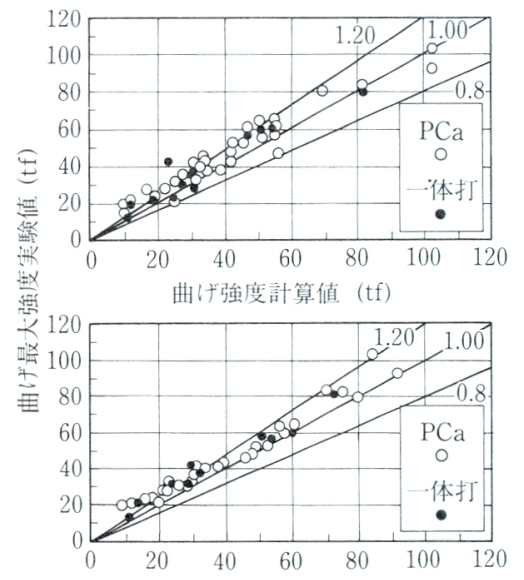

曲げ降伏強度計算値（tf)

図-14 曲げ強度の実験值と計算値の比較
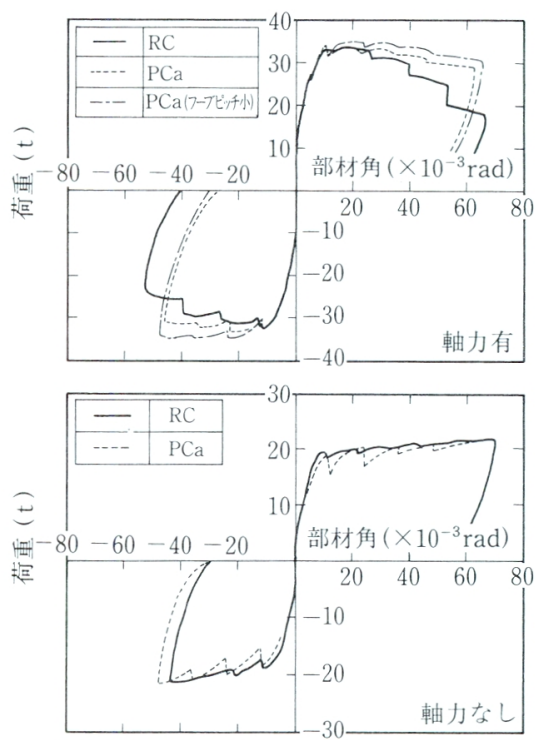

図-15 柱部材の荷重一部材角関係例 (図-14 と異なる継手の場合)

た例である。付着がない場合にやや変形性能が劣る傾向 があるものの，ほぼ一体打設した試験体と同等の強度お よび変形性能を示したと報告されている。

強度および変形能等のマクロ的な性能が, PCa 部材 と一体打設部材とで余り相違しないという, 以上に述べ たような結果は, 柱以外の部材についても指摘されてい る 25 ) 30)。

しかし，本形式継手を用いた PCa 部材では，主とし て部材の端部にスリーブが集中設置されるとともに, 部 材の接合部に敷モルタルやグラウト材で充てんされた目 地部が形成される。そのため, PCa 部材と一体打設と でマクロ的な特性は同様であっても，ミク口的な特性に 違いが見られる場合もある。図一17 ${ }^{29)}$ は柱部材の片持 ち式曲げ破壊試験体の部材脚部において計測されたすべ り変位量の頂部水平変位量に対する比と部材角との関係 を示したものである。同図によると, PCa 部材は一体 打設した試験体に比べてすべり変位量が大きく, 特に軸 力のない試験体ではその差の大きいことが示されてい 


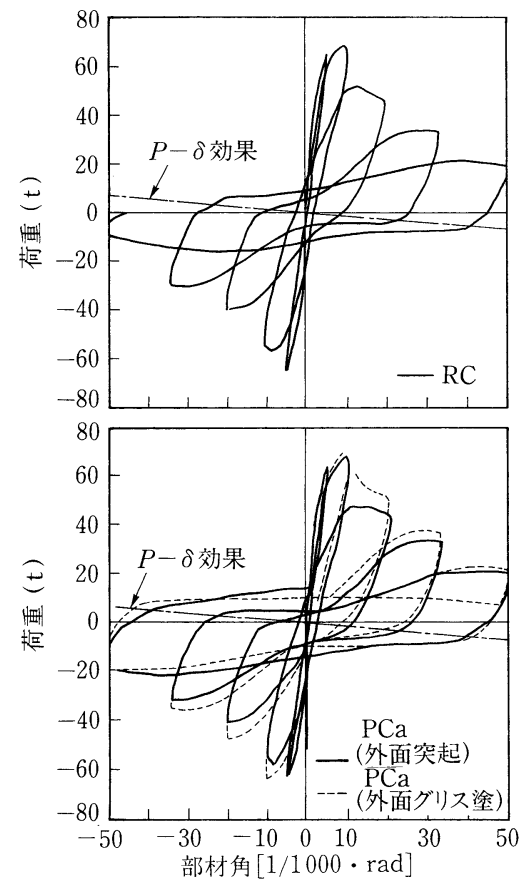

図-16 荷重一部材角関係に及ぼす スリーブ外周面の影響

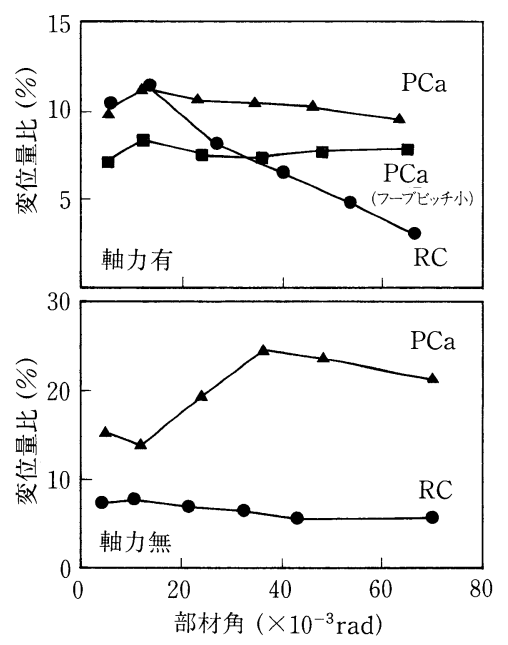

図-17 頂部水平変位量に対する すべり変位量の割合

る。さらに, PCa 柱部材の全体変形量をせん断変形, 曲げ変形, 滑り変形および部材接合目地部の目開きに分 割して示した図-18 ${ }^{29)}$ によると，全体変形のうち 30 $50 \%$ は部材接合目地部の目開きによるものであり, 変 形が進むにつれてその割合が増加すること等が指摘され ている。

\section{3. 施 工 性}

グラウト充てん式鉄筋継手は，鉄筋位置誤差の吸収性 が良いなどの長所を持つものの, 溶接継手等と異なり, 施工後に超音波探査試験などの直接的な試験を用いて継 手部の品質検査を行うことができない。それ故, その施 工にあたっては次のような点に留意しておく必要があ る。

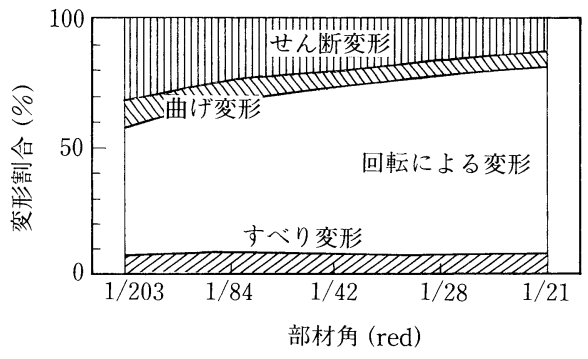

図-18 $\mathrm{PCa}$ 柱部材の全体変形に対する変形 要素の割合

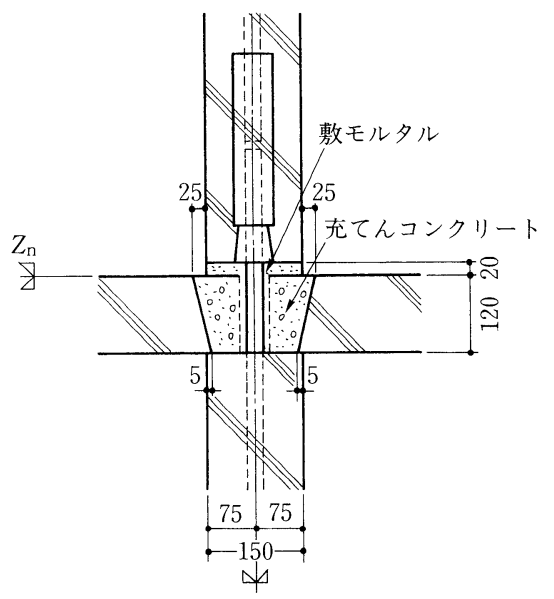

図-19 PCa 壁部材の納まり例

まず，PCa 部材製作時には，正確な位置へのスリ一 ブの設置, 所定の鉄筋埋め込み長さの確保およびスリー ブ内へのコンクリートペーストの流入防止等についての 注意が重要である。各メーカーでは, 品質確保および施 工性向上を目的として，型枠へのスリーブ取り付けのた めの専用治具およびスリーブ端部分のシール材等が開発 されている。また，現場での PCa 部材設置時には，鉄 筋表面への異物の付着，スリーブ内への異物混入の排除 等にも十分留意する必要がある。

2.1 項にも記述したようにグラウト材の品質は継手性 能に直接影響するため，グラウト材の品質管理は最も重 要な項目である。実用化されている継手のグラウト材 は, 工場でプレミックスされているため, 品質管理は比 較的容易に行えると思われる。しかし，継手内部に確実 に充てんするために必要な流動性, 継手性能を発揮する ための压縮強度，硬化までの養生方法等については，各 継手の仕様書に明記された管理值および管理方法を遵守 する必要がある。さらに，これらの品質管理が確実に実 施されるよう，グラウト作業は指定の講習等を受けた認 定者が実施することになっている。

PCa 部材の継目である目地部分も確実に充てんする 必要がある。壁 $\mathrm{PCa}$ 部材等のように厚さが薄い部材で は，図-1931) に示すように，目地部は敷モルタルで充 てんできるが, 柱 PCa 部材のように比較的厚い部材で は，底面全体に確実にモルタルを敷き詰めることが難し い。そこで，目地部もグラウトで充てんする方法が検討 


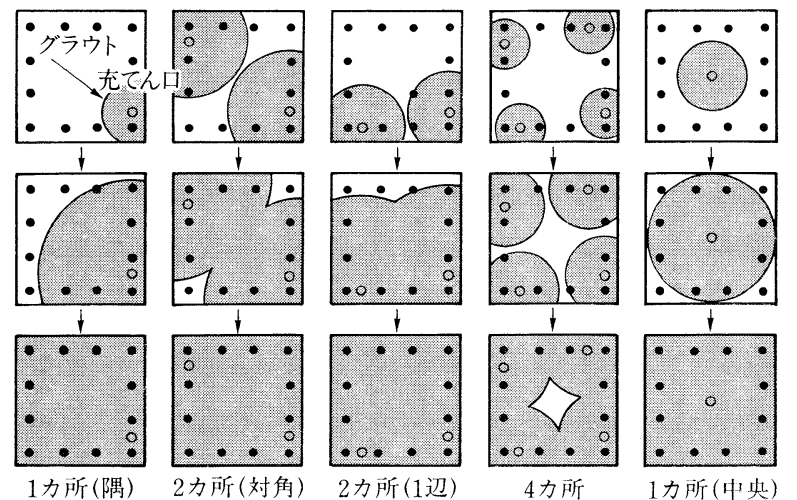

図一20 充てん状況に及ぼすグラウト充てん位值の影響

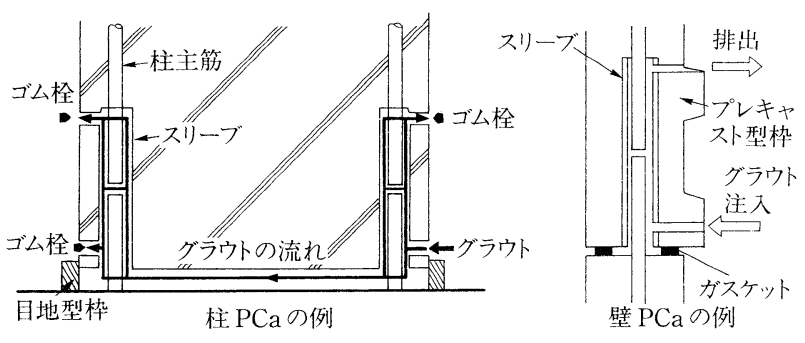

図-21 スリーブ内および目地部へのグラウト一括充てん例

されている。図-2032) は, PCa 柱を模擬したアクリル 製の模型を用いて目地部へのグラウト充てん状況を観察 した結果である。同図によると柱中央部あるいは柱周辺 部のどこか一力所から充てんすれば，目地部およびス リーブ内を一括して確実に充てんできることが示されて いる。一括して充てんする場合の目地部外周の密閉方法

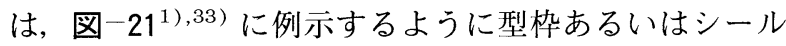
材を用いる方法等が実施されており，同方法によれば継 手内と目地部にグラウトが同時に充てんできたと報告さ れている。

\section{4. 今後の展望}

本稿では, 1970 年代から始まったグラウト充てん式 鉄筋継手の研究の概要を紹介した。

先にも記述したように，グラウト充てん式鉄筋継手は ますます利用が増大し，それに伴って，性能の向上，ス リーブの短小化, 施工性向上等, 継手の高度化が要求さ れ，ニーズに答えるべく研究および開発が進んでいくと 考えられる。本稿がそのような赹勢に対して，少しでも 役に立てば幸いである。なお，開発体制としてはこれま でのように開発メーカー，大学等の研究機関およびゼネ コン等各分野で重複した研究を行うのではなく, 研究の 効率化を図るために共同で系統立てた研究を行う等も有 効であると考える。

最後に，本稿執筆に際し，日本スプライススリーブ怢) および東京鉄鋼(森)より資料の提供を睗わるとともに，多 くの文献を引用ならびに参考にさせていただいた。記し て謝意を表します。

\section{参 考 文 献}

1）建築技術：最近の複合化工法を探る（建築のプレキャス 卜化と生産性向上)，建築技術, 1992.1

2）(社日本コンクリート工学協会 : プレキャスト化の現状と 将来，コンクリート工学, Vol. 30, No. 11, 1992. 11

3）建築技術：コンクリートの PCa 化手法の実際，建築技 術, 1995.5

4) 別所佐登志 : 鉄筋継手の種類と力学性状，コンクリート 工学, Vol. 29, No. 12, pp. 20 32, 1991. 12

5）真鍋正宏・萩原銀蔵，佐々木育平：充填式継手に関する 一実験，建築学会大会学術講演梗概集，pp. 1003 1004, 1972. 10

6) 大下正照・黒正清治・福原正志：異形パイプを用いた $\mathrm{RC}$ プレキャストパネルの付着接合法に関する基礎的実 験研究, 建築学会大会学術講演梗概集, pp. 1287 1288, 1975. 10

7）池田捷也・畑野 肇他 2 名：スプライススリーブを用い た鉄筋継手の引張繰返し荷重下における疲労強度の実験 的研究, 建築学会大会学術講演梗概集, pp. 271 272, 1973. 10

8）畑野 肇・亀田泰弘他 2 名：鉄粉系無宿収縮モルタルと スリーブを用いた太径異形鉄筋に関する研究（火災後の 継手性状に関する研究), 建築学会大会学術講演梗概集, pp. 1225〜1226, 1973. 10

9）池田捷也・松崎育弘他 6 名：フラスタム型スプライスス リーブ鉄筋継手工法を用いた $\mathrm{RC}$ 柱の挙動に関する実 験研究，（その 2) スプライススリーブ継手単体の試験 結果, 建築学会大会学術講演梗概集, pp. 1419 1420, 1974.10

10）社日本コンクリート工学協会 : 鉄筋の継手および定着の 設計施工に関するシンポジウム発表論文集，1976. 3

11）中野清司 - 狩野芳一他 2 名：鉄筋継手の分類之性能判定 規準の流れ一鉄筋継手を有する $\mathrm{RC}$ 部材の挙動に関す る研究 (その 1,2$)$, 建築学会大会学術講演梗概集, pp. 555 558, 1985. 10

12) (社日本建築センター：鉄筋継手性能判定基準 (1982 年), ビルディングレター, 1983.8

13）社日本建築センター：建設省住指発第 31 号「特殊な鉄 筋継手の取扱いについて」, ビルディングレター, 1991.3

14）林 芳尚，清水良平他 2 名：電縫鋼管スリーブを用いた グラウト充填式鉄筋継手の基砧的性能，コンクリート工 学論文集，第 5 巻，第 2 号, pp. 65 75, 1994.7

15）池田捷也・松崎育弘他 3 名：異形鉄筋継手「NMB スプ ライススリーブ」の特徵と性能評価，(社日本コンクリー 卜工学協会，鉄筋の継手および定着の設計施工に関する シンポジウム発表論文集, pp. 17〜20,1976.3

16）小倉弘一郎： NMB スプライススリーブ工法による鉄筋 継手，鋼材クラブ一太径鉄筋の利用に関する研究委員会 資料，1973.9

17）松崎育弘・寺尾文孝・舟山勇司：鋼管内充填式鉄筋継手 を有する RC 梁部材の挙動に関する研究 (その 1,2$)$, 建築学会大会学術講演梗概集, pp. 147 150, 1987. 10

18）林 芳尚・清水良平他 2 名：鋼管スリーブを用いたグラ ウト充填式継手における鉄筋の付着応力度一すべり特 性，建築学会構造系論文集，第 462 号, pp. 131 139, 1994. 8

19）後藤幸正・大塚浩司：引張を受ける異形鉄筋周辺のコン クリートに発生するひび割れに関する実験的研究，土木 学会論文報告集，第 294 号, pp. 85 100, 1980.2

20）林 芳尚・見分一郎他 3 名：鋼管スリーブを用いたグラ ウト充填式継手に関する研究（その 5,6$)$, 建築学会大 会学術講演梗概集, pp. 21 24, 1995.8

21）中野克彦・松崎育弘他 3 名：モル夕ル充填式継手を用い たプレキャスト部材の構造性能評価に関する研究（その $1,2)$, 建築学会大会学術講演梗概集, pp. 29 32, 1995. 
22) (社日本建築センター : 構造計算指針・同解説, 1983.8

23）高実子光・槙谷栄次他 2 名：モル夕ル充填式継手を有す る $\mathrm{PCa}$ 部材の構造性能に関する研究（その 1,2 ), 建 築学会大会学術講演梗概集, pp. 207〜210, 1994.9

24）中田浩之・林 芳尚他 2 名：鋼管スリーブによるグラウ 卜充填式継手を有する PCa 柱の力学特性, コンクリー 卜工学年次論文報告集, Vol. 17-2, pp. 261 266, 1995

25）阿部文昭・寺腰 茂・末永保美 : 壁式プレキャス卜鉄筋 コンクリート造建物の水平接合部に関する実験的研究 (その 1,2 ), 建築学会大会学術講演梗概集, pp. 621〜 $624,1985.10$

26）槙谷栄次・望月 重他 2 名 : ネジスリーブ継手を有する プレキャスト部材の力学挙動に関する研究，コンクリー 卜工学年次論文報告集, Vol. 13-2, pp. 175 180, 1991

27）小椋克也・槙谷栄次他 2 名：機械式鉄筋継手を有する $\mathrm{PCa}$ 壁の力学的挙動に関する研究, コンクリート工学 年次論文報告集, Vol. 14-2, pp. 119 124, 1992
28) 岡田健一・槙谷栄次他 2 名：WR-PC に関する共同研 究 (その 1 3), 建築学会大会学術講演梗概集, pp. 521 526, 1993. 9

29）小澤健一・槙谷栄次他 2 名：モルタル充填式継手を有す る $\mathrm{PCa}$ 部材の耐震性能に関する研究, コンクリート工 学年次論文報告集, Vol. 16-2, pp. 301 306, 1994

30）高実子光・槙谷栄次他 2 名：モル夕ル充填式継手を用い た PCa 耐力壁脚部の力学的挙動に関する研究, 建築学 会大会学術講演梗概集, pp. 27〜28, 1995. 8

31）(財)日本建築学会「建築工事標準仕様書・同解説 JASS 10 プレキャストコンクリート工事」

32）武田 健・林 芳尚他 3 名：鋼管スリーブを用いたグラ ウト充填式継手に関する研究（第 2 報）一継手を用いた $\mathrm{PCa}$ 柱の施工性，奥村組技術研究年報，No. 20, pp. 119 124, 1994

33）吉田 正・常田賢一：20 cm 厚の型枠を初採用，日経 コンストラクション, pp. 80〜85, 1995. 9

\section{国際会諳言ニュース}

\section{セメント化学に関する第 10 回国際会議}

\section{0th Int. Congress on the Chemistry of Cement}

日 時: 1997 年 6 月 2 日〜 6 日

場 所 : Göteborg (Sweden)

主 催 : ACI ほか

内 容 : Clinker production

- New processes

- Low energy clinker formation

- Utilization of industrial by-products and wastes

- Application of mineralizers, modifiers and activators

- Correlating process parameters with clinker properties

- Clinker structure and mineralogy

Portland, blended and special (e. g. high alumina) cements

- Rheology

- Hydration kinetics and microstructure development

- Structural models for hydrated cementitious pastes

- Chemical and physical shrinkage

- Influence of blends or additions of combustion ash, slag, silica fume or rice husk ash

- Influence of mixing techniques and curing conditions

Utilization of admixtures ; water reducers, air entrainers, accelerators, retarders and polymers

- Mechanisms ; admixture chemical $\leftrightarrow$ cement interaction

- Influence of admixtures on microstructure development

- Combined admixtures and their mixing techniques
- Influence of type, dose, addition time and mixing time

Performance and durability of concrete and cement based systems

- Pore structure and its influence on permeability and diffusivity of gases (e. g. carbon dioxide), liquids (e. g. water) and dissolved ions (e. g. chlorides)

- Physio-chemical(e. g. sulphates), thermal (e. g. freeze-thaw) and biological degradation, including environmental and synergistic effects

- Cement aggregate compatibility (e. g. alkali-aggregate reactions) and structure $\leftrightarrow$ performance relationships

- Influence of physico-chemical aspects during early material history on durability (e. g. high curing temperature $\rightarrow$ secondary ettringite formation)

- Modelling of degradation processes

- Life cycle analyses

Developments in Characterization Techniques

- Nuclear Magnetic Resonance (NMR)

- X-ray diffraction (XRD)

- Diffraction by synchrotron radiation or neutrons

- Scanning electron microscopy

- Other techniques

論文申込 : '96 年 4 月 15 日までに 200 語以下の英文概要 3 部 を下記まで送付のこと。

連絡先: The 10 th ICCC organizer,

c/o Congrex,

Box 5078, S-402 22 Gothenburg, Sweden

Fax. : +4631203620 